\title{
TRACHYONYCHIA ASSOCIATED WITH ALOPECIA AREATA AND SECONDARY ONYCHOMYCOSIS
}

\author{
Jose L. Anggowarsito \\ Renate T. Kandou
Department of Dermatovenereology Medical Faculty of Sam Ratulangi University
Prof. Dr. R. D. Kandou Hospital Manado \\ Email: jlaaxx@gmail.com
}

\begin{abstract}
Trachyonychia is an idiopathic nail inflammatory disorder that causes nail matrix keratinization abnormality, often found in children, and associated with alopecia areata, psoriasis, atopic dermatitis, or nail lichen planus. Trachyonychia could be a manifestation of associated pleomorphic or idiopathic disorders; therefore, it may occur without skin or other systemic disorders. There is no specific diagnostic criteria for tracyonychia. A biopsy is needed to determine the definite pathologic diagnosis for nail matrix disorder; albeit, in a trachyonychia case it is not entirely necessary. Trachyonychia assessment is often unsatisfactory and its management is focused primarily on the underlying disease. We reported an 8-year-old girl with twenty dystrophic nails associated with alopecia areata. Cultures of nail base scrapings were performed two times and the final impression was trichophyton rubrum. Conclusion: Based on the clinical examination and all the tests performed the diagnosis of this case was trachyonychia with twenty dystrophic nails associated with alopecia areata and secondary onychomycosis. The majority of trachyonychia cases undergo spontaneous improvement; therefore, a specific therapy seems unnecessary. Onychomycosis is often difficult to be treated. Eradication of the fungi is not always followed by nail restructure, especially if there has been dystrophy before the infection.
\end{abstract}

Keywords: trachyonychia, alopecia areata, onychomycosis.

\begin{abstract}
Abstrak: Trakionikia adalah inflamasi kuku idiopatik yang menyebabkan gangguan keratinisasi matriks kuku, sering terjadi pada anak, dan terkait dengan alopesia areata, psoriasis, dermatitis atopik atau lichen planus kuku. Trakionikia bisa merupakan manifestasi dan asosiasi dari gangguan pleomorfik atau idiopatik, sehingga dapat terjadi tanpa kelainan kulit dan gangguan sistemik lainnya. Tidak terdapat kriteria diagnosis khusus untuk trakionikia. Diagnosis patologik definitif untuk kelainan matriks kuku ialah melalui biopsi, namun hal ini tidak disarankan. Penanganan trakionikia sering tidak memuaskan dan fokus manajemen terutama ditujukan pada penyakit yang mendasarinya. Kami melaporkan seorang anak perempuan berusia 8 tahun dengan dua puluh kuku distrofik disertai alopesia areata. Kultur dari kerokan dasar kuku dilakukan dua kali dengan hasil trichophyton rubrum. Simpulan: Berdasarkan pemeriksaan klinis dan pemeriksaan penunjang, diagnosis kasus ini ialah trakionikia dengan 20 kuku distrofik disertai alopesia areata dan onikomikosis sekunder. Mayoritas kasus trakionikia dilaporkan mengalami perbaikan spontan sehingga terapi khusus untuk trakionikia sering tidak diperlukan. Onikomikosis sering sulit diobati. Eradikasi jamur tidak selalu disertai perbaikan struktur kuku, terutama bila telah terjadi distrofi kuku sebelum infeksi.
\end{abstract}

Kata kunci: trakionikia, alopesia areata, onikomikosis. 
Trachyonychia is also referred to as twenty-nail dystrophy (TND) ${ }^{1.2}$ or sandpapered nails ${ }^{3}$ which is an idiopathic inflammatory nail disorder that causes nail matrix keratinization abnormality - often in children, and associated with alopecia areata, psoriasis, atopic dermatitis or nail lichen planus. ${ }^{1,2}$ The clinical features are typically: rough surfaces of the nail, brittleness, and excessive nail destruction. Several nails can be involved; however, the diagnosis does not require the involvement of all twenty nails. ${ }^{1}$ Trachyonychia has also been reported in autoimmune conditions such as selective IgA deficiency, vitiligo, and chronic graft-versus-host disease. ${ }^{3}$ Nail changes can undergo spontaneous improvement at the age of 20-25 years with no scar tissue; therefore, therapy is often not necessary. ${ }^{1}$

Onychomycosis occurs in $15 \%$ of the world's population, and $40 \%$ of them are over 60-years-old. ${ }^{1}$ Onychomycosis is a fungal infection of superficial forms with a diagnostic rate of $30 \%$. Pathogens are mainly dermatophytes (85\%) and nondermatophytes (Candida sp. 15\%). Tricophyton rubrum are the most common dermatophytes (>90\%), ${ }^{4}$ followed by Tricophyton mentagrophytes var. interdigitale and Epidermophyton floccosum. ${ }^{5-7}$ In immunosuppressed individuals, Candida sp. is the only causal pathogen and it usually manifests itself as a proximal subungual onychomycosis (PSO) with periungual inflammation. Severe onychomycosis may include all 20 nails. ${ }^{1}$

The nail, a complex integument structure, may be associated with a variety of primary and secondary diseases. Nail abnormalities may have implications for the quality of life and have psychosocial aspects. ${ }^{1}$ The therapy of nail disorders is often difficult; ${ }^{6}$ therefore, knowledge of the structure and physiology of nails is important in confirming the diagnosis and for managing better therapy. ${ }^{1,6}$

\section{CASE REPORT}

In September 21, 2012 an 8-year-old girl came to the Dermatovenereology
Clinic of Prof. Dr. R. D. Kandou Hospital with cracked and chipped nails on both hands and feet (Fig. 1A). Small pits, the size of the tip of a needle in the 5 finger nails of the right hand, each having 4 or 5 nail pits, had occured 13 months before without any itching or discoloration. The number of pits increased, and they partly fused into the nail groove in both hands. The curves of the nails appeared thinned but thickened around the sides, especially at the fingertips. Over the next one month, this disorder had spread to the toe nails of both feet, followed by a yellow-brownish discoloration, and there were transverse white lines above both thumb and big toe nails. The nails turned to a darker color, raised, thickened, and were also brittle and chipped.

There were no complaints when the fingers came in contact with cold temperatures. No hair loss or patchy baldness was found. There were no histories of jaundice, diabetes, hyper and hypothyroid, and of other skin diseases (pellagra, porpyria, psoriasis, herpes, syphilis, contact irritants). Histories of long-term consumption of drugs (antibiotics or steroids), pulmonary infection, and allergies were denied. Infant and toddler growth appeared normal. There were histories of atopy in both parents; moreover, the patient's mother suffered from asthma. There was a history of repeated weekly contacts from November 2011 with river sand as the patient followed her father in his sand mining operation.

On physical examination we found that the patient's general condition was good along with her nutritional status and vital signs Dermatological examination of the 20 nails showed onycholisis, dystrophic nails, Beau's lines, yellowish discoloration, subungual hyperkeratosis, red lunulae, onychomadesis, and proximal paronychia (Fig. 1A). There was no sign of lateral paronychia, pitting, longitudinal lines, salmon patches, pterygium, or clubbing. The dorsal side of the $2^{\text {nd }}$ toe of the right foot encountered erythematous papules which were well demarcated with numular 
sizes, as well as erosion, excoriation, squama, and lichenification (Fig. 1B).

Laboratory tests in October 17, 2012 showed results within normal limits. Direct microscopy examination using $20 \%$ potassium hydroxide of samples from the right thumb nail scrappings revealed spores and long septal hyphae. The first culture of nail base scrapings (samples dated September 21, 2012) macroscopically showed colonies of filaments, white like cotton, with a yellow background; and microscopically showed long septal hyphae with microconidia in regular orders like water droplets along the hyphae. The final impression was Trichophyton rubrum (dermatophytes). Based on these findings the current diagnosis was established as a trachyonychia and a circumscript neurodermatitis in the dorsal side of the $2^{\text {nd }}$ toe of the right foot (Fig. $1 \mathrm{~B}$ ). A biopsy to confirm the diagnosis is required. Differential diagnoses for this case were onychomycosis, lichen planus, nail psoriasis, and nail atopic dermatitis.
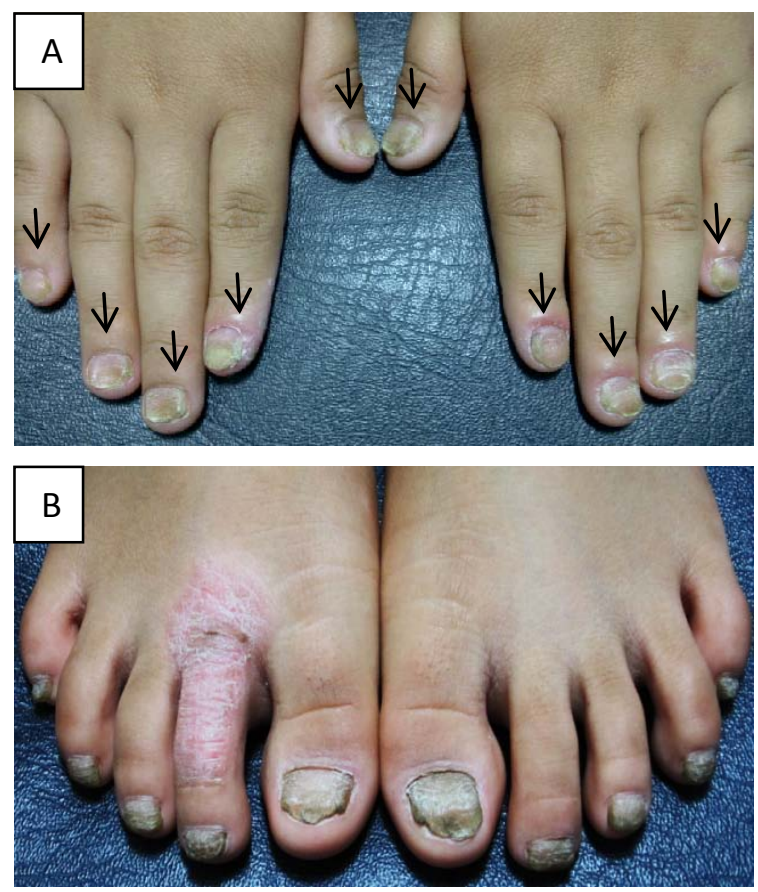

Figure 1. A, Trachyonychia (arrows). B, Circumscript neurodermatitis (diamond arrow) at the dorsal side of the $2^{\text {nd }}$ toe of the right foot (September 21, 2012).
The therapeutical management of this patient was oral cetirizine $1 \mathrm{x} 10 \mathrm{mg}$ in the morning, chlorpheniramine maleate $1 \times 4$ $\mathrm{mg}$ in the evening, and 2-time applications of topical $0.1 \%$ diflucortolone valerate ointment on the skin lesions (dorsal side of the $2^{\text {nd }}$ toe of the right foot).

On the second visit (October 10, 2012), the patient complained of hair loss. There were multiple patchy hair loss areas without hair follicles near the hairline at the back of the head and the neck area around the left ear (Fig. 2). There was no itching, scars, or histories of injuries on those spots. The surrounding scalp skin looked normal without inflammation or erosion. Complaints about nail abnormalities and skin lesions still remained. A direct microscopical examination using 20\% potassium hydroxide for the scalp and hair did not reveal endothrix, exothrix, or hyphae. The second culture of the nail base scrapping (samples dated October 18, 2012) confirmed the first culture result as T. rubrum. The results of the scalp and hair cultures from samples dated October 23, 2012 using Sabouraud dextrose agar showed no growth of any fungi. The diagnosis was changed to trachyonychia associated with alopecia areata and secondary onychomycosis et causa $T$. rubrum. The differential diagnosis were nail atopic dermatitis, nail psoriasis, lichen planus, and circumscript neurodermatitis (which had improved on the dorsal side of the $2^{\text {nd }}$ toe of the right foot). The pasient was given an oral pulse therapy of itraconazole $1 \mathrm{x} \quad 150 \mathrm{mg} /$ day for 1 week/month in 3 cycles and the 2-time applications of topical $0.1 \%$ diflucortolone valerate ointment on the skin lesion (the dorsal side of $2^{\text {nd }}$ toe of the right foot) was continued.

On the last visit (December 11, 2012), the patient still had hair loss on the previous locations with no other new spots emerging; however, the patient complained about nail abnormalities. The differential diagnoses were nail atopic dermatitis, nail psoriasis, and lichen planus. A definitive diagnosis could not be confirmed because a 
nail biopsy was refused by both parents. Oral pulse therapy of itraconazole was continued for 3 cycles followed by a liver function test which resulted in normal limits. Alopecia areata was treated with 2time topical applications of $0.05 \%$ clobetasol propionate; however, topical $0.1 \%$ diflucortolone valerate for the skin lesion was discontinued.
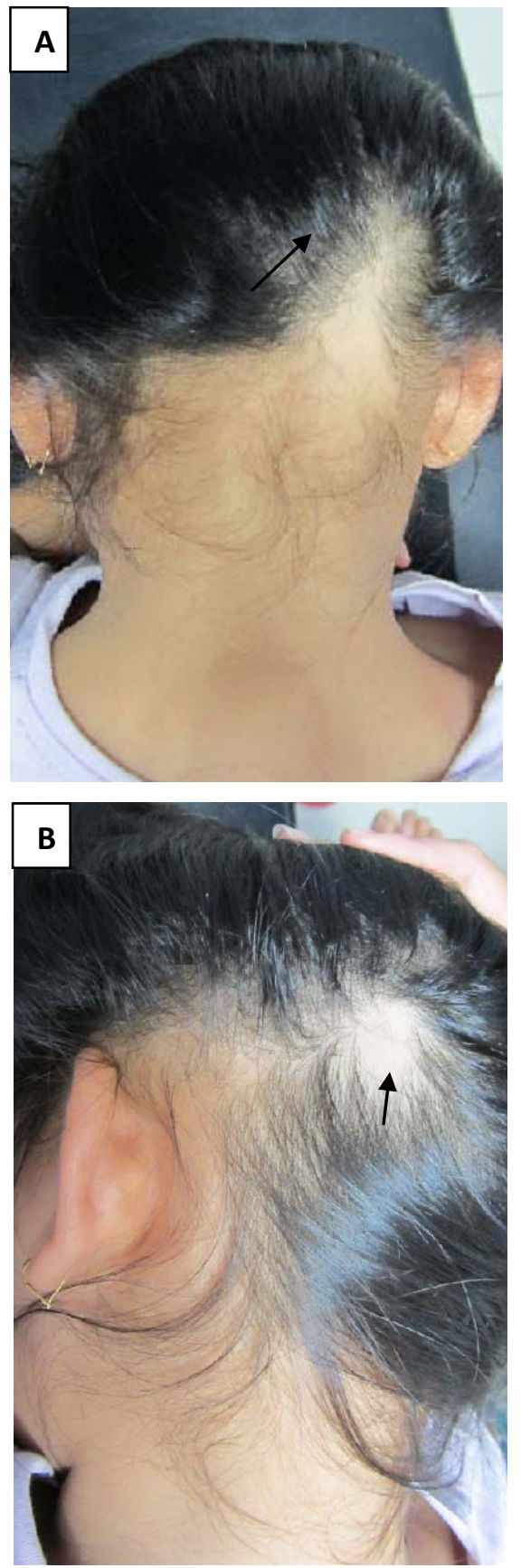

Figure 2. Alopecia areata: A, At the back of the head (regio occipitalis). B, At the neck area around the left ear (regio temporalis sinistra) (October 23, 2012).

\section{DISCUSSION}

Trachyonychia was first described by Alkiewicz (1950) and was first called: Twenty-Nail Dystrophy (TND) ${ }^{1}$ or Sandpapered Nails by Hazelrigg et al. (1977). ${ }^{2}$ The term TND is preferably used if it involves all 20 nails. ${ }^{2,8}$ Trachyonychia is often without symptoms and patients often complain of the nails disfigured appearance. $^{2,6}$ Trachyonychia has an insidious onset during the peak ages of 312 years old ${ }^{8}$ although it can occur at any age. ${ }^{9}$ Trachyonychia could be a manifestation of associated pleomorphic or idiopathic disorders, or it may occur without skin and other systemic disorders (Table 1$)^{8}$

Table 1. Abnormalities associated with trachyonychia $^{8}$

Alopecia areata

Atopic dermatitis

Autoimmune hemolytic anemia

Bart syndrome

Congenital cutaneous candidiasis

Dyskeratosis congenita (Zinsser-Engman-Cole syndrome)

Graft-versus-host disease

Hereditary punctuate palmoplantar keratoderma (Brauer-Buschke-Fischer syndrome)

Hydrotic ectodermal dysplasia (Couston syndrome)

Ichthyosis vulgaris

Idiopathic thrombocytopenic purpura

Immunoglobulin A deficiency

Incontinentia pigmenti

Koilonychia

Lichen planus

Nail-patella syndrome

Onychodysplasia of the index fingers

Pachyonychia congenital

Pemphigus vulgaris

Primary biliary cirrhosis

Psoriasis

Sarcoidosis

Trauma

Vitiligo

Alopecia areata commonly accompanies trachyonychia with a prevalence of $3.65 \%$ with a typical onset in childhood. ${ }^{8}$ 
TND with alopecia areata occurs more frequently in children (12\%) than in adults (3.3\%), ${ }^{6}$ whereas idiopathic TND only occurs in children. ${ }^{2}$ Trachyonychia accompanied by alopecia areata is more common in males. ${ }^{10}$ The most common form is totalized alopecia (alopecia universalis), ${ }^{2,6,8,11}$ but it can also manifest itself with mild hair loss. ${ }^{8}$ Hair loss and nail changes may occur simultaneously or separately. ${ }^{8,11}$

Among children with alopecia areata, $50 \%$ have abnormal nails, while among adults 20\%. ${ }^{1,2}$ In alopecia areata, nail abnormalities are typically in the geometric pitting form and trachyonychia. ${ }^{1,2,6,8}$ The geometric pitting is formed by small curves, superficially, and distributed in a regular pattern (grid-like) in longitudinal and/or transverse rows. Other nail abnormalities of alopecia areata are: punctate leukonychia, lunula erythema (mottled), onycholysis, and onychomadesis. ${ }^{1,2}$ The cosmetic concern of 20 nails is the primary reason to seek treatment.

Alopecia areata was discovered on the $2^{\text {nd }}$ visit, which may have occurred previously and was not noticed by the patient nor her parents. The early form of nail disorders of such patients are minor curves without itching or color changes then they multiply. Some of them fuse and are marked with a pitting nail in alopecia areata. This patient's brittle and easily chipped nails were in the proximal parts, suggesting onychomadesis which were marked by Beau's lines. There was a history of repeated contacts with the river sand, and in the course of the disease this patient had nail discoloration, which may have occured due to a secondary infection of onychomycosis (The culture resulted in T. rubrum).

Trachyonychia has been reported in autosomal dominant transmission ${ }^{12-14}$ and its occurance in monozygotic twins. ${ }^{15}$ This transmission form is associated with alopecia areata that occurs in twins and several other family members. Idiopathic trachyonychia is more common and more widely reported in literature. ${ }^{8}$ This patient was the only child; moreover, no other family members suffered from such a disorder although her family had a strong history of atopy.

Clinical forms of nail trachyonychia are thin, opaque, dull, and often hyperkeratotic cuticles which also look like sand paper with excessive longitudinal patterns. $^{1-3,5,8}$ The nail discoloration was opaque and dull. Based on the degrees of severity, trachyonychia is divided into mild and severe types. The severe type is frosted and has sandpaper dull nails, meanwhile the mild type still has shiny nail surfaces with diffuse lines and pittings. Koilonychia can be found in both types. ${ }^{8}$ Early lesions form of patient's are irregular pittings; some are partially joined to form tranverse grooves accompanied by thinning of the nail curves. Thickening and discoloration (dull yellow-brownish), especially on the distal edge of the nail, are accompanied by removal of the nail plate and roughness of the nail surface. Tissues under the nail appear thickened, especially on the thumbs and toes. During the clinical assesment on the first visit, neither longitudinal lines nor pterygium formations were found.

Trachyonychia caused by lichen planus is considered rare $(<10 \%) .{ }^{8,16}$ Oral lesions are common forms of lichen planus accompanying nail lichen planus. ${ }^{17}$ In general, nail lichen planus in the form of trachyonychia has been proposed as another form of lichen planus due to the thinning, splitting, and atrophy of the nails, and is rarely associated with pterygium scar tissue formation, ${ }^{18}$ and often have spontaneous healing., ${ }^{8,17}$ In children, nail lichen planus in the form of trachyonychia is often without skin or mucosal lesions. ${ }^{17}$ In this patient, there were thinning nails, discoloration, and subungual dystrophic hyperkeratosis, without longitudinal ridging, pterygium formation, and lichen planus lesions on the skin or mucosal layer.

Nail abnormalities of patients with psoriasis as many as $10-55 \% .{ }^{19}$ Psoriasis is found in $25-50 \%$ of children. ${ }^{20}$ A total of $5 \%$ of nail psoriasis lesions are not accompanied with skin lesions. ${ }^{19,20}$ Pitting 
of the nail psoriasis describes intermittent psoriasis lesions of the nail matrix. Irregular pitting in nail psoriasis can be distinguished with pitting in alopecia areata or in atopic dermatitis, especially if it is accompanied by discoloration (oily spots), onycholysis, or subungual hyperkeratosis. ${ }^{20}$ Changes in the nail structure might increase the risk of secondary infection due to bacteria, candida, or dermatophytes. ${ }^{19,20}$ Trachyonychia in psoriasis causes thicker nail plates, meanwhile trachyonychia associated with nail lichen planus experiences thinner nails. Chronic skin lesions of psoriasis involving the nail fold can evolve into trachyonychia. ${ }^{19}$ This patient's history of irregular pitting as early lesions, paronychia, onycholysis, and onychomadesis were the underlying concern of nail psoriasis, although there were no psoriasis skin lesions.

Trachyonychia also occurs in atopic dermatitis especially hand eczema that often leads to changes of the nails such as: papules, vesicles, and erythema of the proximal nail fold or hyponychium. Damage of the nail matrix creates irregular pittings and Beau's lines; moreover, onychomadesis can occur in severe cases. ${ }^{20}$ Trachyonychia resulting from atopic dermatitis in children can occur for many months without abnormalities on mucocutaneus layers. ${ }^{8,20}$ The course of the disease varies, but it can improve spontaneously in later months or years. A majority of $50 \%$ occurred in the first 6 years of life. $^{20}$ Nail discoloration, especially in the lunulae can also be caused by alopecia areata, psoriasis, ${ }^{1-3,6,20}$ lupus erythematosus, dermatomyositis, congestive heart failure, reticulosarcoma, carbonmonoxide poisoning, or lymphogranuloma venereum. ${ }^{20}$ This patient had a history of severe atopy along with her parents and other family members. In this case, underlying suspicion of atopic dermatitis was a cause of trachyonychia. Erythema of her proximal nail fold suggested an inflammatory process of a secondary infection.

Nail fragility (brittle nails/onychorrhexis) can be dermatological disorders, which can be found in alopecia areata, lichen planus, psoriasis, and onychomycosis. ${ }^{1,2}$ Onychomycosis is a fungal infection (dermatophytes, non-dermatophytes, mold and yeast, especially Candida sp). ${ }^{1,2,4,5,7}$ Onychomycosis is clinically classified as distal-lateral subungual onychomycosis (DLSO), white superficial onychomycosis (WSO), proximal subungual onychomycosis (PSO), candidal onychomycosis, and total dystrophic onychomycosis. $^{1-5}$ All clinical forms of onychomycosis may develop TND. ${ }^{1,2,4}$

Distal-lateral subungual onychomycosis (DSLO) are common clinical forms in children. ${ }^{10}$ Onychorrhexis was also complained by this patient, especially concerning fragile and chipped nails. Thickening and discoloration of the nails, especially the big toe in the distal and lateral sides were also found in patient. Most of onychomycosis affects the toe nails (80\%) and the most common cause is T. rubrum (90\%). ${ }^{1,2,4,7,10}$ Although the majority are caused by secondary infection, T. rubrum has been considered as a main pathogen. ${ }^{7}$ Dermatophytes nail infections are often in the form of DLSO with onycholysis and subungual hyperkeratosis which can also be found in nail psoriasis. ${ }^{21}$ C. albicans and T. mentagrophytes which are variations of interdigital infections, are more rarely to be seen. ${ }^{5,7}$ Onychomycosis in children caused by Candida sp. is less common than by dermatophytes infection. Sometimes combined infections occur, and it is not uncommon that T. rubrum is found from the isolate. ${ }^{10,21}$ Infections of $C$. albicans or Candida sp. are often marked with paronychia, onychodistrophic, and onycholysis, while others rarely cause onychomycosis paronychia. ${ }^{21}$ Common clinical forms of onychomycosis caused by DLSO type of dermatophytes infection are $93 \%,{ }^{7} \quad$ onychodystrophy $56 \%$, and paronychia due to candida infection $50 \%{ }^{10}$ If onychomycosis in children with trachyonychia is suspected, microbiological diagnosis should be done immediately, so that appropriate therapy can be given immediately to prevent more widespread 
lesions. $^{5,7}$

Positive cultures of nail scrapings and nail bed tissues on the Sabouraud dextrose agar, with or without cycloheximid, confirmed the clinical diagnosis of onychomycosis. The result of the first culture of nail scraping and distal side of nail-bed tissue obtained $T$. rubrum which also confirmed by the second culture, although the yellowish discoloration and paronychia of the proximal nail fold was often more common in patients with candida infections.

There was no specific clinical criteria for the diagnosis of the disease causing tracyonychia. The incidence of abnormalities on onychodermal lines indicates a problem with the nail matrix and the separation of the nail plate at the distal tip of the finger. ${ }^{22}$ Abnormalities in trachyonychia are the disorders of nail matrix; so to establish a definite pathologic diagnosis matrix biopsy is required. On the contrary, some experts suggested that the pathological diagnosis of trachyonychia was not entirely necessary as it was a benign nature of the disorder and it did not cause scars. ${ }^{2,8}$ Moreover, even though it was caused by lichen planus in children, it might recover spontaneously. ${ }^{2,6,8,9}$ Another reason not to encourage a biopsy in children is the consideration of the objection of the parents. $^{8,17}$ Gordon et al. ${ }^{8}$ did not recommend biopsy of the nail disorders such as lichen planus, trachyonychia, and idiopathic nail atrophy. ${ }^{8}$

If the biopsy of the proximal nail fold is carried out, the nail matrix will present a view of spongiosis, and exocytosis lymphocytic infiltrates in epithelial nails. ${ }^{23,24}$ This is also found in trachyonychia with alopecia areata ${ }^{3,6,8,11,24}$ and most cases of idiopathic trachyonychia; ${ }^{11,23,24}$ besides that, it has also been reported to have histopathological similarities to nail lichen planus $^{16-18,24}$ and nail psoriasis. ${ }^{3,6,19,24}$ After removing the psoriasis and lichen planus histopathologically, parakeratosis on trachyonychia can be distinguished to determine the cause, either alopecia areata, atopic dermatitis, or idiopathic. ${ }^{23,24}$ Another nail pathological change is hypergranulosis which may occur in idiopathic trachyonychia, nail lichen planus, and nail psoriasis. Inflammation in the nail matrix can interfere with keratinization process, causing abnormal expression and accumulation of keratohyalin granules in the nail plate. These changes can be permanent although the inflammatory process has subsided. ${ }^{25}$ Histopathological changes in trachyonychia are more common in the proximal nail matrix and proximal nail fold ventral side associated with clinical changes occuring on the dorsal nail plate. This situation confirms the occurrence of variations in the shape of the nail plate which is not uniform due to the inflammatory activity in the nail matrix. Sandpaper nail shape indicates a consistant inflammatory activity, and shiny nails trachyonychia shape indicate there was a latent period of the normal nail matrix. ${ }^{8}$ The variability of this inflammatory process explained why there was no scarring lesions in trachyonychia which differed with other nail matrix disorders. ${ }^{6,8}$ Consideration of the advantages and disadvantages of the nail biopsy for the diagnosis of pathological causes of trachyonychia concluded that a biopsy should not be a standard part of the management procedures. ${ }^{8}$

Assessment of trachyonychia is often unsatisfactory as it focuses primarily on the management of the underlying disease. In children, most trachyonychia cases experience spontaneous resolutions. ${ }^{2,6,8,9}$ Our patient's situation is reflected in the lack of the decision by the parents to procede with invasive measures such as biopsy and injection therapy. Therapy of trachyonychia with alopecia areata especially the universal/totalized type is more difficult, but can undergo spontaneous resolution in several years. ${ }^{24}$ Tosti et al. observed the nail lichen planus in children up to 10 years that improved in the first 6 years of therapy with or without systemic corticosteroid therapy. ${ }^{17,20}$ Some of the success of topical therapy and systemic injections for trachyonychia have 
been reported. These successes are derivatives of vitamin $\mathrm{A}$ as a selective retinoid receptor (tazarotene $0.1 \%$ gel) for psoriasis trachyonychia, ${ }^{26}$ psoralen plus ultraviolet A (PUVA), ${ }^{27}$ intralesional triamcinolone injection at the proximal nail fold, ${ }^{17,28}$ oral prednisolone, ${ }^{17}$ acitretin and etretinate for severe psoriasis, ${ }^{19}$ even biotin supplementation, anti-malaria, and more aggressive treatments such as cyclosporin. ${ }^{8}$ It is important to remember that the vast majority of cases of trachyonychia are selflimiting and treatment is not really necessarily. ${ }^{2,6,8,9,20}$

Onychomycosis therapy is difficult because the infection occurs in the nail and the degree of nail growth is long enough (fingernails $3 \mathrm{~mm} / \mathrm{month}$ and toenails 1 $\mathrm{mm} / \mathrm{month}){ }^{2}$ so that new clinical cures will appear after several years or more. ${ }^{8}$ The success of the eradication of the fungi is not always followed by normal shapes of the nails, especially if there have been dystrophic nails before infection. This dystrophic circumstance might facilitate secondary pathogens and saprophyte infections on nails, ${ }^{5}$ as found in this case. In immune-competent children, topical antifungal therapy should be considered first, such as the application of imidazole with occlusion, to increase penetration. ${ }^{7}$ The use of nail lacquer (amorolfine 15\% and ciclopirox olamine $1.5 \%$ ) is not so advisable, because of the risk of being inhaled by children. ${ }^{4,7}$ Fluconazole, itraconazole, and terbinafine are safe and efficient for children. ${ }^{7}$ Terbinafine is the most effective fungicidal as antidermatophytes are currently available. $^{4,5,7,329}$ Onychomycosis therapy with terbinafine was given $250 \mathrm{mg} /$ day for 3-6 months. ${ }^{29}$ Itraconazole is an anti-fungal, including yeast, dermatophytes, molds, and non-dermatophytes, but is not as effective as terbinafine against dermatophytes. ${ }^{4,70}$ Both drugs accumulate in the skin, nails, hair, and sebum for a long time, although they have been eliminated in the plasma. ${ }^{5,30,31}$ Itraconazole can be used as an intermittent/pulse therapy for onychomycosis. $^{4,30,31}$ Itraconazole pulse therapy for onychomycosis in children in doses of $5 \mathrm{mg} / \mathrm{kg} /$ day in capsule dosage $100 \mathrm{mg}$ should be given as follows: 10-15 $\mathrm{kg}$ bodyweight with 1 x $100 \mathrm{mg} /$ alternant 1 day; 16-20 kg with $100 \mathrm{mg} /$ day; 21-40 kg with 2x100 mg/day; and bodyweight $>40$ kg with 2x200 mg/day. ${ }^{31}$ This patient was given oral daily dosages of $150 \mathrm{mg}$ itraconazole in pulse therapy for 3 cycles. Monitoring of liver function was performed before treatment and at the end of third cycle. The selection of itraconazole was based on the drug cost and its availability in our health facilities.

Alopecia areata in patients treated with clobetasol propionate $0.05 \%$ cream, being applied 1-2 times on the area of alopecia, is the first line therapy according to the British association of dermatologists guidelines for the management of alopecia areata in 2012, although it is stated that without treatment alopecia areata may experience spontaneous remission (80\%) within 1 year. $^{32}$ Alopecia areata in children is often difficult to overcome when it is followed by changes in the nature and behavior of the children as noticed by their parents, and should be referred to psychologists for further assessment. Literature stated that even without treatment alopecia areata may experience spontaneous remission (80\%) within 1 year. In general, psychological aspect of alopecia areata in children are often impaired, because of the changes in the nature and behavior of children as noticed by their parents. ${ }^{32}$ This patient was referred to psychologists for further assessment.

Promising alternative therapies for onychomycosis are laser therapy, photodynamic therapy, iontophoresis, and ultrasound. $^{33}$ These four non-invasive alternative therapies may shorten the duration of treatment and improve patient adherence to long-term therapy. The photodynamic therapy, iontophoresis, and ultrasound might be used in combination with the systemic therapy to avoid adverse drug reactions. ${ }^{33,34}$ The efficacy of alternative therapies still needs more randomized controlled trials to evaluate the 
long-term mycological therapy and observations.

Education and information that the eradication of fungal infection is not always followed with nail repair, especially when there has been dystrophy before infection, although there will be no scar tissue as informed to the worrisome parents. It is suggested that to prevent onychomycosis one should always attempt to dry the nails after being wet. Children are advised to dry the skin around the nails after a bath or in contact with water or after sweating and change socks if they have become wet through sweating. ${ }^{8}$

\section{CONCLUSION}

We reported a trachyonychia case with twenty dystrophic nails associated with alopecia areata and secondary onycomycosis in an 8-year-old girl. There were several differential diagnoses of this case: atopic dermatitis, nail psoriasis, nail lichen planus, and nail abnormalities accompanied by secondary onychomycosis. Discoloration, thickening, and lifting of the nail plate of the distal-lateral parts which occurred later in this case indicated a secondary onychomycosis. Signs of nail lichen planus were found in the form of splitting, atrophy of the nails, onycholysis, longitudinal ridging, pitting, discoloration, dystrophy, subungual hyperkeratosis, nail thickening, leukonychia, but without the formation of scar tissue as well as pterygeum without skin and mucosal lesions. Erythema of the proximal nail fold, history of pitting of the nails, onychomadesis, and Beau's lines are markers of nail disorder due to atopic dermatitis, whereas paronychia, onycholysis, and onychomadesis can also be found in nail psoriasis and alopecia areata. The definitive diagnosis should be better obtained through a histopathological examination, but the diagnosis of trachyonychia can simply be identified through clinical examination alone, without a biopsy. The majority of cases undergo spontaneous improvement, and therapy did not seem necessary.

\section{REFERENCES}

1. Tosti A, Piraccini BM. Biology of nails and nail disorders. In: Goldsmith LA, Katz SI, Gilchrest BA, Paller AS, Leffell DJ, Wolff K, editors. Fitzpatrick's Dermatology in General Medicine (Eighth Edition). New York: Mc. Graw Hill Inc., 2012; p.1009-30.

2. Tosti A, Piraccini BM. Hair, nails and mucous membranes. Nail disorders. In: Jean L. Jorizzo, Joseph L. editors. Bolognia Dermatology. St. Louis: Mosby, 2008; p.1019-36.

3. Baran R, Barnett JM, Bodmann MA, Cohen PR, Rich P, Scher R, et al. Disease of the skin appendages. Disease of the nails. In: James WD, Berger TG, Elston DM, editors. Andrews' Disease of the Skin Clinical Dermatology. Oxford, UK: Saunders-Elsevier, 2000; p.781-93.

4. Roberts DT, Taylor WD, Boyle J. Guidelines for treatment onychomycosis. British Journal of Dermatology. British Association of Dermatologists. 2003;148:402-10.

5. Hay RJ, Ashbee HR. Mycology. Superficial mycosis. In: Burns T, Breathnach S, Cox N, Griffiths C, editors. Rook's Textbook of Dermatology (Eighth Edition). UK: Wiley-Blackwell, a John Wiley \& Sons, Ltd, Publication, 2010; 34-55, 63-9.

6. Tang W. Nail and nail disorders. The Hong Kong medical diary. Medical bulletin; Dermatology Research Centre, Faculty of Medicine the Chinese University of Hong Kong. November 2010; 15(11):13-17.

7. Lateur N. Onychomycosis in children. Fifth Meeting of the European Nail Society: (C) 2003 Dermatology Online Journal. Brussel, Belgium. DOJ. 9(1):17E.

8. Gordon KA, Vega JM, Tosti A. Trachyonychia: A comprehensive review. Symposium nails part-1. IJDVL. 2011;77(6):640-5.

9. Sakata S, Howard A, Tosti A, Sinclair R. Follow up of 12 patients with trachyonychia. Australasian Journal of Dermatology. 2006;47(3):166-8.

10. Romano C, Papini M, Ghilardi A, Gianni C. Onychomycosis in children: a survey of 46 cases. Mycoses. 2005;48(6):430-7.

11. Tosti A, Fanti PA, Morelli R, Bardazzi F. Trachyonychia associated with alopecia areata: A clinical and pathologic study. J Am Acad Dermatol. 1991;25:266-70. 
12. Pavone L, Li Volti S, Guarneri B, La Rosa M, Sorge G, Incorpora G. Hereditary twenty-nail dystrophy in a Sicilian family. J Med Genet. 1982;19:337-40.

13. Balci S, Kanra G, Aypar E, Son YA. Twenty-nail dystrophy in a mother and her 7-year-old daughter associated with balanced translocation 46, XX, $\mathrm{t}(6 \mathrm{q} 13 ; 10 \mathrm{p} 13)$. Clin Dysmorphol 2002; 11:171-3.

14. Arias AM, Yung CW, Rendler S, Soltani K, Lorincz AL. Familial severe twentynail dystrophy. J Am Acad Dermatol. 1982;7:349-52.

15. Karakayali G, Lenk N, Gungor E, Gur G, Alli N. Twenty-nail dystrophy in monozygotic twins. J Eur Acad Dermatol Venereol. 1999;12:192-3.

16. Makkar M, Pandey P, Dixit A, Kapur K, Mahajan NC. Twenty nail dystrophy associated with lichen planus in a child: A case report. Iran $\mathrm{J}$ Dermatol. 2011;14:113-6.

17. Tosti A, Piraccini BM, Cambiagi S, Jorizzo M. Nail lichen planus in children clinical features, response to treatment, and long-term follow-up. Arch Dermatol. 2001;137(8):1027-32.

18. Kanwar AJ, De D. Lichen planus in children. Symposium pediatric dermatosis. IJDVL. 2010; 76:4:366-372.

19. Tosti A, Bellavista S, Iorizzo M, Vincenzi C. Occupational trachyonychia due to psoriasis: Report of a case successfully treated with oral acitretin. Contact Dermatitis. 2006;54:123-4.

20. Paller AS, Mancini AJ. Nails. Disorder hair and nails. In: Bonnet C, Gabbedy R, editors. Hurwitz S. Clinical Pediatric Dermatology. A Textbook of Skin Disorders of Childhood and Adolescence (Fourth Edition). Edinburg: SaundersElsevier, 2011; 158-66.

21. Brahmono K. Onikomikosis dan berbagai diagnosis bandingnya: abstrak. Symposium dan workshop: Dermatologi dari klinik ke laboratorium. PMKIKSDMI. Jakarta 6-7 Oktober 2012;15.

22. Luxenberg EL, Silverman RA. Nail disorders in children. Dermatology nursing (c) 2010 Jannetti Publications, Inc. Medscape dermatology news. Maret 2010; 22:1.

23. Grover C, Khandpur S, Reddy BS,
Chaturvedi KU. Longitudinal nail biopsy: Utility in 20-nail dystrophy. Dermatol Surg. 2003;29:1125-9.

24. Chien P, Kovich O. Alopecia universalis with twenty-nail dystrophy (trachyonychia) (2008 Dermatology Online Journal. New York. 2008; 14:5:24.

25. Fanti PA, Tosti A, Cameli N, Varotti C. Nail matrix hypergranulosis. Am J Dermatopathol 1994;16:607-10.

26. Soda R, Diluvio L, Bianchi L, Chimenti S. Treatment of trachyonychia with tazarotene. Clin Exp Dermatol 2005;30:301-2.

27. Halkier-Sorensen L, Cramers $M$, Kragballe K. Twenty-nail dystrophy treated with topical PUVA. Acta Derm Venereol. 1990;70:510-1.

28. Khoo BP, Giam YC. A pilot study on the role of intralesional triamcinolone acetonide in the treatment of pitted nails in children. Singapore Med J. 2000;41:66-8.

29. Pappas PG. Terbinafine. In: Kauffman CA, Pappas PG, Sabel JD, Dismukes WE, editors. Essential of Clinical Mycology (Second Edition). New York: Springer, 2011; 113-7.

30. Andes DR, Dismuskes WE. Azoles. In: Kauffman CA, Pappas PG, Sabel JD, Dismukes WE, editors. Essential of Clinical Mycology (Second Edition). New York: Springer, 2011; 61-83.

31. Huang PH, Paller AS. Itraconazole pulse therapy for dermatophyte onychomycosis in children. Arch pediatr Adolesc Med. (c) American Medical Association. Chicago. June 2000;154:614-8.

32. Messenger AG, McKillop J, Farrant P, McDonagh AJ, Sladden M. British Association of Dermatologists' Guidelines for the Management of Alopecia Areata 2012. The British Journal of Dermatology (C2012 Blackwell Publishing 2012; 166:5:916-26.

33. Gupta AK, Simpson F. Device-based Therapies for Onychomycosis Treatment. Skin therapy letter. (c) 2012 SkinCareGuide.com. 2012; 17:9.

34. Altshuler GB, Anderson RR, Manstein D, Zienzi HH, Smirnov MZ. Extended theory of selective photothermolysis. Lasers Surg Med. 2001;29:5:416-32. 